\title{
Geoscience international: the role of scientific unions
}

\author{
Alik Ismail-Zadeh ${ }^{1,2,3}$ \\ ${ }^{1}$ Karlsruhe Institute of Technology, Institute of Applied Geosciences, Karlsruhe, Germany \\ ${ }^{2}$ Russian Academy of Sciences, Institute of Earthquake Prediction Theory and Mathematical Geophysics, \\ Moscow, Russia \\ ${ }^{3}$ International Union of Geodesy and Geophysics, IUGG Secretariat, Helmholtz Centre Potsdam, \\ GFZ German Research Centre for Geosciences, Potsdam, Germany
}

Correspondence to: Alik Ismail-Zadeh (alik.ismail-zadeh@kit.edu)

Received: 27 May 2016 - Revised: 11 November 2016 - Accepted: 14 November 2016 - Published: 29 November 2016

\begin{abstract}
International geoscientific unions (geounions) have been coordinating and promoting international efforts in Earth and space sciences since the beginning of the 20th century. Thousands of scientists from many nations and specific scientific disciplines have developed ways of cooperation through international unions and learned how to work together to promote basic geosciences. The unions have been initiating, developing, and implementing international cooperative programmes, setting scientific standards, developing research tools, educating and building capacity, and contributing to science for policy. This paper analyses the role of geounions in and their added value to the promotion of geoscience internationally in the arena of the existing and emerging professional societies of geoscientists. The history of the geounions and the development of international cooperation in geosciences are reviewed in the paper in the context of scientific and political changes over the last century. History is considered here to be a key element in understanding and shaping the future of geounions. Scientific and organisational aspects of their activities, including cooperation with international and intergovernmental institutions, are analysed using the example of the International Union of Geodesy and Geophysics (IUGG). The geounions' activities are compared to those of professional societies. Future development of scientific unions and their role in the changing global landscape of geosciences are discussed.
\end{abstract}

1

\section{Introduction}

Basic geoscience advances fundamental knowledge to satisfy curiosity, generates new ideas and principles, and formulates new hypotheses and theories that help in the understanding of the Earth and its environment in space. Fundamental geoscientific studies assist in revealing secrets of the Earth's natural resources, in reducing humanity's destructive impact on the environment, in warning about disasters associated with natural events, in improving the quality of life for Earth's growing population, and in making our planet more sustainable. Scientists have been developing geosciences through an assembly of scientific elements such as objects, methods, instruments, and theories, and institutional tools, such as journals, scientific meetings, research institutions, and universities (Good, 2000).
Often geoscientific research extends over political boundaries, and hence requires organised international cooperation, that is, joint work by geoscientists from many nations to initiate, develop and/or promote specific scientific research requiring an international dimension. International scientific unions promote Earth and space sciences and develop international cooperation in basic scientific research and in science for society.

International scientific unions are non-profit nongovernmental scientific organisations with an international scope of activities, international membership, and international governance. For almost 100 years, the geoscientists working in the unions have been constructing ways of research cooperation regardless of their personal national affiliation. Their interests have extended well beyond the pursuit of pure knowledge, especially by trying to develop links not only with themselves, but also with policymakers 
and industry. International cooperation in geosciences ranges from individual relationships between scientists or scientific groups of different nations through a more formal non-governmental mechanism of cooperation developed by international scientific unions to formal intergovernmental agreements within the United Nations (UN) and its specialised agencies. Along with these mechanisms, bilateral and regional (e.g. the European Union) mechanisms of international cooperation have also been developed.

The subjects of this paper are the international geoscientific unions (or geounions) grouped under the umbrella of the International Council for Science (ICSU). A comprehensive historical review of the development of the ICSU geounions and international cooperation in geosciences is beyond the scope of this paper. There are a number of publications on the topic, referred to partly in the paper, where scientific internationalism has been analysed since the 19th century, including the international polar years and the International Geophysical Year (e.g. Launius et al., 2010), the most recent works on Alexander von Humboldt's contribution to geophysical sub-disciplines within the evolving differentiation in the natural sciences (Wulf, 2015), and on the development of atmospheric sciences (Fleming, 2016), as a few to be mentioned.

The basic goal of this work is to provoke a discussion on the future of geounions in the changing global geoscience landscape and to understand their role in the past, current and future international scientific cooperation. A constructive reshaping of various activities of geounions, closer collaboration among each other, strengthening cooperation with intergovernmental organisations, and developing a closer relationship with professional societies of geoscientists may provide a way to meet the scientific and technological challenges of the modern world. Various activities of geounions over the last century are analysed in the paper.

Forman (2002) argued that the future of science cannot be predicted by extrapolating current scientific concepts, but can be foreseen by considering the general social and cultural conditions under which scientific knowledge is being produced at present and is likely to be produced in the future. Accordingly, the future development of geounions cannot simply be extrapolated from their current activities, but it should be analysed in a retrospective way considering the conditions in the past (e.g. changing political, scientific and technological landscapes) and the current conditions under which the unions have been operating.

In the following two sections of this paper, the development of international cooperation in geosciences since the 19th century (Sect. 2), and the IUGG's activities for the last century (Sect. 3), are reviewed and analysed. The development could be split into four major historical periods:

i. earlier development before World War I (WWI);

ii. after WWI and before World War II (WWII); iii. after WWII through the Cold War and the Perestroika; and

iv. recent (since 2000s) development.

The earlier development of the international cooperation in geoscience was driven mainly by European countries, and Britain, France and Germany played significant roles in the cooperation. In the pre-WWII period of the development, activities of geounions were predominantly discipline-oriented and concentrated geographically mainly in and performed by scientists from the Allied Countries, which founded or joined the geounions during this period. After WWII, international cooperation became more inclusive, expanding to many countries, including China, Germany, Russia, and economically less affluent countries. New players, such as intergovernmental scientific agencies and UN programmes, changed the landscape of international research cooperation, and geounions developed a cooperative relationship with the UN agencies. The recent period is characterised by strengthening research cooperation through interdisciplinary and transdisciplinary programmes, fostering scientific development for science policy within a more complicated scientific landscape with emerging policy-oriented international programmes (e.g. the Future Earth programme or the Integrated Research on Disaster Risk (IRDR) programme, both initiated by the ICSU), with active participation of geounions and with increasing activities of professional societies of geoscientists.

In Sect. 4, professional societies such as the American Geophysical Union, the European Geosciences Union, and the Asia Oceania Geosciences Society are presented, and similarities and differences between geounions and the professional societies are analysed. The added value of international geoscientific unions is assessed in Sect. 5 covering topics related to science for society, scientific and outreach programmes, capacity building, products, services, and networking. In Sect. 6, the role of international unions in future promotion of geosciences including scenarios for their future development are discussed, and the main points of the paper are summarised. As many acronyms of international organisations are used in this paper, all the acronyms are listed in Appendix A that provides the full names of the relevant organisations.

Special note: natural scientists employ the so-called "data assimilation technique" to forecast future behaviour of a dynamic system (e.g. weather, climate, ocean circulation, lithosphere dynamics) using past data and a model of the dynamic system. Unions are dynamic social systems, and this approach can be applied qualitatively (without a quantitative methodology still to be developed for social systems) to the analysis of the past development of a social system to foresee the future of the system's development. In this work, I have tried to use an "assimilation" approach (historical data and IUGG model) to analyse the past development and to shape the future of the geounions. The paper is neither a purely 
historical nor a science policy one, but combines both elements in a way to understand the role of international scientific unions and their added value to scientific development, and to help geoscientists to appreciate the contribution of geounions in fostering research cooperation for a century.

\section{Development of international cooperation in geosciences}

\subsection{Earlier development}

It is difficult to trace back to when international cooperation in Earth and space sciences began. It is even more complicated to outline all the ways in which the advancement of geoscience internationally has been influenced by individuals, politicians, and the communities they created. More evident is that this cooperation became important in the early 19th century, especially in the fields of astronomy, geology, geodesy, and geophysics (Greenaway, 1996). In some fields of geosciences, international collaboration was essential, because related observations had to be made across national borders. For example, in the early 1800 s, French natural scientists J.-B. Biot (1774-1862) and F. Arago (1786-1853) worked on Spanish territory to measure the Paris meridian arc. In the first decades of the 19th century, when maritime navigation was dependent on magnetic compasses and the variations in terrestrial magnetism had to be measured and mapped, E. Sabine (1788-1883), an Irish astronomer and geophysicist, A. von Humboldt (1769-1859), a Prussian geographer and naturalist, and a few others, organised widespread magnetic observations (Collier, 2014). This motivated C. F. Gauss (1777-1855), a German mathematician, together with A. von Humboldt and W. Weber (1804-1891), a German physicist, to found in 1836 the Göttingen Magnetic Union, the first worldwide network of magnetic observatories. This international organisation promoted a cooperative scheme of simultaneous observations in which more than 50 observatories distributed over five continents took part (Chapman, 1955; Linthe, 2007). Soon after, other geoscience disciplines established their own international cooperative efforts.

In 1861, J. Baeyer (1794-1885), a Prussian general and geodesist, proposed that the states of Europe should work together on the measurement of the size and shape of the Earth, and described methods to achieve this aim. King William I of Prussia (1797-1888) accepted the proposal and invited the countries concerned to subscribe to the plan. The geodetic community established the Mitteleuropäische Gradmessung (a central European geodetic association) in 1862, which became the Association Géodésique Internationale (the International Association of Geodesy, IAG) in 1886 (AngusLeppan, 1984).

Conferences and international contacts were sporadic before the second part of the 19th century. Several important international events - the first International Astronomical
Congress (Heidelberg, 1863), the first International Congress of Geographers (Antwerp, 1871), the first International Meteorological Congress (Leipzig, 1872), the first International Geological Congress (Paris, 1878), and the first International Polar Year (1882-1883) (e.g. Hildebrandsson and Hellmann, 1907; Greenaway, 1996) - laid the foundation for worldwide cooperation in Earth and space sciences.

Prince Albert I of Monaco (1848-1922), who devoted time and resources to oceanography, granted his patronage to the establishment of the International Marine Association in 1900 (IAPSO, 2015). J. Milne (1850-1913), a British geologist, who was invited by the Japanese government to Tokyo in 1875, established the Seismological Society of Japan together with British and Japanese physicists and seismologists. The First International Conference on Seismology was held in Strasbourg in 1901, and the International Seismological Association was founded in 1904 (Schweitzer, 2003; Jacobs and Börngen, 2012).

Along with the development of international communities of geoscientists, many national science academies established cooperation by the end of the 19th century. Most of the academies were old and located in Europe, among them the Royal Society (the British academy established in 1660), the Académie des Sciences in Paris (in 1666), the Reale Accademia dei Lincei in Rome (operating in 1603-1651, and then since the 1870s), the Königlich-Preußische Akademie der Wissenschaften in Berlin (1700), the Imperial Russian Academy of Sciences in St. Petersburg (1725), and the Bayerische Akademie der Wissenschaften in Munich (1759). The US National Academy of Sciences was founded in 1863, and was ready to cooperate with the European and other academies. During the reign of the Emperor Meiji (18671912), the Japanese government started to develop international scientific cooperation, especially in seismology (mentioned above), and the Japan Academy of Sciences was established in 1879.

According to Greenaway (1996), the inception of the modern pattern of international scientific collaboration started in 1897, when the Austrian geologist E. Suess (1831-1914), then the President of the Austrian Academy of Sciences, invited several academies to set up an association of national academies. In 1899, representatives of 19 European and US academies met in Wiesbaden, Germany, to establish the International Association of Academies (IAA). Although many topics concerned organisational issues, the Royal Society presented at the meeting a proposal on international cooperation in measurements of an arc of the meridian running through the African territories controlled by Britain, France, and Germany. This cooperation required political agreement on the scientific work in the region between those three countries (Greenaway, 1996), and diplomacy stepped into geoscience and facilitated international scientific cooperation (e.g. Sztein, 2016).

The IAA was active until WWI, discussing, initiating, and promoting international scientific cooperation among na- 
tions, including collaboration in seismology, terrestrial magmatism, atmospheric electricity, and gravity measurements and analysis, particularly in Africa. The IAA played an important diplomatic role in promotion of science; for instance, the academies assisted scientists in getting permission to enter foreign countries for fieldwork and other scientific activities (Greenaway, 1996). However, while diplomacy for science worked well until the early 20th century, international scientific cooperation was not restored after WWI for several decades.

Although German academies played an important role in the establishment of the IAA and international geoscientific associations (e.g. in geodesy and seismology), the involvement of Germany and other countries of the Central Powers as well as Russia in geoscience cooperation was interrupted by WWI (and the 1917 Red October Revolution in the case of Russia) and resumed to the full extent only after WWII (e.g. the Federal Republic of Germany became an IUGG member in 1951, and the Soviet Union in 1954). It is known, however, that, immediately after the end of WWI, about 200 members of the academies of neutral nations called on the members of the academies of the Allied Nations "for cooperation in order to prevent science from becoming divided, for the first time and for an indefinite period, into hostile political camps" (Scientific Events, 1919).

By the outbreak of WWI in 1914, international organisations for astronomy, geodesy, seismology, meteorology, geomagnetism, geoelectricity, and oceanography had already been established. The war interrupted the operation of these bodies, although some were kept active by then-neutral nations. During WWI, some scientific leaders from the Allied Nations gave thoughts to the post-war renewal of international scientific cooperation. Though early efforts in international cooperation within international associations and the network of national academies (IAA) were very successful, discussion between existing geoscientific societies and national academies was limited, forcing scientists to devise a new model of cooperation. Representatives of the scientific academies of the Allied Nations met in London, Great Britain, on 9-11 October 1918 and then in Paris, France, on 26-29 November 1918 and decided to foster international scientific cooperation and to establish an international research council (IRC) (Wood, 1919a). The IRC was active until 1931, when it was renamed the International Council of Scientific Unions (ICSU). The ICSU modified its name in 1998 to the International Council for Science, retaining the existing acronym.

\subsection{Post-WWI period}

The first IRC General Assembly consisting of delegates from 11 countries (Belgium, Canada, France, Italy, Japan, New Zealand, Poland, Romania, Serbia, the United Kingdom, and the United States of America) was held in Brussels, Belgium, on 18-28 July 1919 and attended by King Albert of Belgium and the Belgian Minister of Science and Arts. Brazil, Australia, South Africa, Greece, and Portugal joined the IRC at the time of this meeting (IRC, 1919). The assembly defined four main objectives of the IRC:

i. "to coordinate international efforts in the different branches of science and its applications;

ii. to initiate the formation of international associations or unions deemed to be useful to the progress of science;

iii. to direct international scientific action in subjects which do not fall within the province of any existing association; and

iv. to enter, through the proper channels, into relations with the Governments of the countries adhering to the Council to recommend the study or questions falling within the competence of the Council" (Lyons, 1919).

Already at the meeting in Paris in 1918, representatives of national academies decided to initiate the formation of scientific unions to organise and promote international cooperation; particularly, a resolution was passed in favour of the establishment of an international geophysical union "for the purpose of initiating and promoting researches in geophysics" (Wood, 1919a), to be made up of all existing scientific groupings dealing with physical sciences of the Earth. The formation of the unions was carried further at the meeting in Brussels. The establishment of the first two geounions instituted in Paris - the International Astronomical Union (IAU) and the IUGG - was finalised by approving their statutes and future activities (Lyons, 1919). The IUGG included several branches of science for which special organisations had existed for many years, well before WWI. They were reconstituted as six sections within the IUGG, each with its own executive committee. Those initial sections were geodesy, terrestrial magnetism and electricity, meteorology, physical oceanography, seismology, and volcanology. The hydrology section was established 3 years later at the 1st General Assembly of the IUGG, which was held in Rome, Italy, in 1922 (Lyons, 1922). The term "Section" was replaced with "Association" at the 5th IUGG General Assembly held in Lisbon, Portugal, in 1933. The eighth association devoted to the study of the cryosphere was added to the union at the 24th IUGG General Assembly held in Perugia, Italy, in 2007.

Two other geounions - the International Geographical Union (IGU) and the International Union of Radio Sciences (Union Radio-Scientifique Internationale, URSI) - were established at the IRC General Assembly in Brussels, Belgium, in 1922. The International Society for Photogrammetry was founded in Vienna, Austria, in 1910. After 70 years of functioning under its original name, the society changed its name to the International Society for Photogrammetry and Remote Sensing (ISPRS) in 1980. The society, which essentially operates as an international scientific union, joined the ICSU in 
2002. The International Society of Soil Science was founded in 1924 in Rome, Italy, mostly by European agro-pedologists to establish standardised methods of soil analysis and soil classification. In 1998, the society was restructured into the International Union of Soil Sciences (IUSS) following its admission as a union member of the ICSU in 1993 (Van Baren et al., 2000). The International Union for Quaternary Research (INQUA) was founded in 1928 by a group of scientists seeking to improve understanding of environmental change during the glacial ages through interdisciplinary research, and joined the ICSU as a full member in 2005.

Until 1939 geounions were actively involved in promoting research and international cooperation in the disciplines of their interests, with occasional multidisciplinary cooperation. Consider IUGG activities for this period as an example. Geodesists needed a new apparatus to measure gravitational characteristics locally, and the IAG promoted the work using new kinds of measurements and making the measurements widely known. Experts in terrestrial magnetism and electricity coordinated activities in studies of magnetic phenomena and cosmic radiation, in standardisation of magnetic instruments, and in magnetic mapping, and established a closer link to the IAU and URSI. In hydrology, research was basically promoted in three directions: the production of energy, irrigation, and flood warning; the association of hydrology established relations with glaciologists to study issues related to water, snow and ice. The association of meteorology fostered international codes for transmission of information about meteorological conditions and proposed to review scientific methods of weather forecasting employed in different countries. Physical oceanographers established a programme of collaboration between bodies concerned with the Mediterranean Sea and the Atlantic and Pacific oceans, and promoted studies of mean sea level and tides. The association of seismology contributed to the establishment of a network of seismic stations, and encouraged national seismic services to perform the installation of seismographs. Volcanologists encouraged the collection of information on active volcanoes, including the substances emitted, temperature and other characteristics of lava and hot springs (see Greenway, 1996, for a detailed description of these and other activities by IUGG associations). The 7th IUGG General Assembly was held in Washington, D.C., USA, in September 1939, with a record-breaking number of delegates (805, including 225 foreign scientists), but unfortunately was overshadowed by the beginning of WWII (IUGG, 1939). During the war, normal communication between member countries became impossible. Although major activities of the union and subscriptions were suspended, the IUGG continued to allocate grants in support of what work could be done by the union associations and other organisations to which it had access (IUGG, 1946).

\subsection{Post-WWII period}

This period in the development of international cooperation in Earth and space sciences is characterised by the change in scientific and political landscapes. The UN formation after WWII broadened the scope of the involvement of geounions in international scientific cooperation via new scientific programmes of the intergovernmental agencies. Compared to intergovernmental organisations, which are constrained by their governmental framework, international scientific unions, being non-governmental organisations, have continued to provide independent advice on scientific subjects of their expertise.

Other major historical factors, such as the Cold War, the decolonisation process, and the dissolution of the Soviet Union (USSR), also left their trace on international research cooperation in the post-WWII period. For example, many African states became IUGG members in the 1950-1960s; China was admitted to the IUGG in 1977 after its admittance to the UN; in 1992, after the USSR's dissolution, the Russian Federation was admitted to the IUGG, but until now only Armenia, Azerbaijan, Estonia and Georgia (of the 14 former Soviet republics) have joined the IUGG.

The major scientific and outreach event during this period of international scientific cooperation was the International Geophysical Year initiated by geounions and organised by the ICSU and the World Meteorological Organization (WMO) in 1957-1958. Also during this period, the scientific landscape started to change from predominantly disciplinary-oriented to multidisciplinary research as a response to the demand for analysis of complex phenomena such as anthropogenic climatic change, natural hazards and new sources of energy. It required geounions, especially the IUGG as a multidisciplinary union, to provide a platform for setting up new projects and programmes, and for discussion of scientific results in a multidisciplinary context. IUGG associations started to organise joint scientific assemblies and multidisciplinary scientific conferences. The IUGG established two union commissions on the study of the Earth's deep interior and on mathematical geophysics.

Before WWII, the geological community considered the International Geological Congresses (IGC) to serve as an international geological organisation, and hence there was no need to set up a new union of geology (Harrison, 1978). In 1948, however, the feasibility of a geological union was again raised. The International Union of Geological Sciences (IUGS) was formed in Paris, France, in 1961, and the union was admitted to the ICSU in the same year. The IGC Council continues to organise scientific congresses in collaboration with and under sponsorship of the IUGS, which holds its general assemblies in conjunction with the IGC. With time, the geological congresses became more multidisciplinary events involving geophysics, geochemistry and other geoscience disciplines. Although a number of earlier attempts had been made in international cooperation in car- 
tography (e.g. a proposal made at the end of the 19th century to develop an international map of the world to present accurately the entire planet, including its natural and human features; Collier, 2014), the International Cartographic Association (ICA) was founded only in 1959, and joined the ICSU as a full member in 2014.

\subsection{Recent development}

The period since the 2000s is mainly characterised by increasing importance and urgency of societal problems, including global warming, environmental change, disaster risks, water scarcity, and food security. The solution of the problems has required not only multidisciplinary, but also interdisciplinary and transdisciplinary approaches to research. Geounions needed to adapt to the new realities, to enhance their activities, and to work together to tackle the challenges. In 2003, E. de Mulder (IUGS President) and U. Shamir (IUGG President) proposed to establish a network of ICSU geounions, and several geounions supported the proposal. Officers of the geounions met in Paris, France, in 2004 at their first summit and agreed to establish an informal network of the unions to promote Earth and space sciences worldwide, to communicate and coordinate scientific activities of individual unions, to enhance the operations of the unions on the knowledge about and experiences of other unions, and to speak on behalf of geounions to the ICSU, UN organisations, and other global stakeholders. At present, the Geounions network (http://www.icsu-geounions.org) is composed of nine international scientific unions of the ICSU: IAU, ICA, IGU, INQUA, ISPRS, IUGG, IUGS, IUSS, and URSI. The synergy of geounions in fostering integrated transdisciplinary research is proven to be powerful. Joint collaborative scientific topics of the geounions have included geoscience data and information, climate, health, megacities, natural hazards and disaster risk, mineral resources, and water. Geounions interact with ICSU interdisciplinary bodies as well as with intergovernmental organisations, and, when necessary, hold geounion summits to exchange information and to discuss new joint activities.

Although the specific goals of each international geoscientific union may be different, the following principal goals of the unions are common: to promote and encourage basic studies of the Earth and its environment in space, and to facilitate international cooperation in geosciences to benefit humanity. The main activities of the international unions include

i. initiation and promotion of new scientific programmes and setting standards for research;

ii. holding scientific meetings around the world with the purpose of sharing knowledge and promoting collegial relationships; iii. dissemination of scientific knowledge via special publications and scientific journals of the unions;

iv. organisation of broad outreach activities, especially in the developing world;

v. promoting science education and capacity building;

vi. encouraging data collection and preservation as well as data services;

vii. cooperation with other international and intergovernmental organisations; and

viii. dissemination of awareness about the Earth, planets, and space among the general public.

In the next section, some of these and other activities are analysed using the IUGG example. The IUGG been chosen because its scientific coverage is broader than that of other geounions. Also, the IUGG has one of the longest histories of international scientific cooperation rooted in the beginnings of the 19 th century.

\section{The International Union of Geodesy and Geophysics}

Today, the IUGG is a vibrant modern scientific union of nations and individual scientists from all over the world promoting research, science education, and capacity building via international cooperation, linking scientific knowledge to societal needs, and working toward a sustainable Earth. The IUGG is dedicated to initiating, promoting and coordinating international scientific studies and observations of the Earth and its environment in space. These (physical, chemical, and mathematical) studies include the shape of the Earth; its gravitational and magnetic fields; geodynamics; the Earth's surface, internal structure, composition, tectonics, and seismology; the generation of magmas; volcanism and rock formation; the hydrological cycle; all aspects of the oceans, the atmosphere, cryosphere, ionosphere, magnetosphere and solar-terrestrial relations; and analogous problems associated with the Moon and other planets of the solar system. The union encourages the application of this knowledge to societal needs, such as the mitigation of impacts from natural hazard events, the sustainable use of energy and mineral resources, and environmental preservation (Ismail-Zadeh and Beer, 2009; IUGG, 2015). The IUGG makes research visible to the international scientific community, to government agencies, to industry, and to the public in general through its scientific, education and outreach activities.

The name of the union might be confusing for those who consider geophysics as a branch of physics dealing with the solid Earth only. In the IUGG, the term "geophysics" is used to refer to a broad range of Earth and space science disciplines as mentioned above. The presence of "geodesy" in the union's name is another puzzle, because geodesy is one 


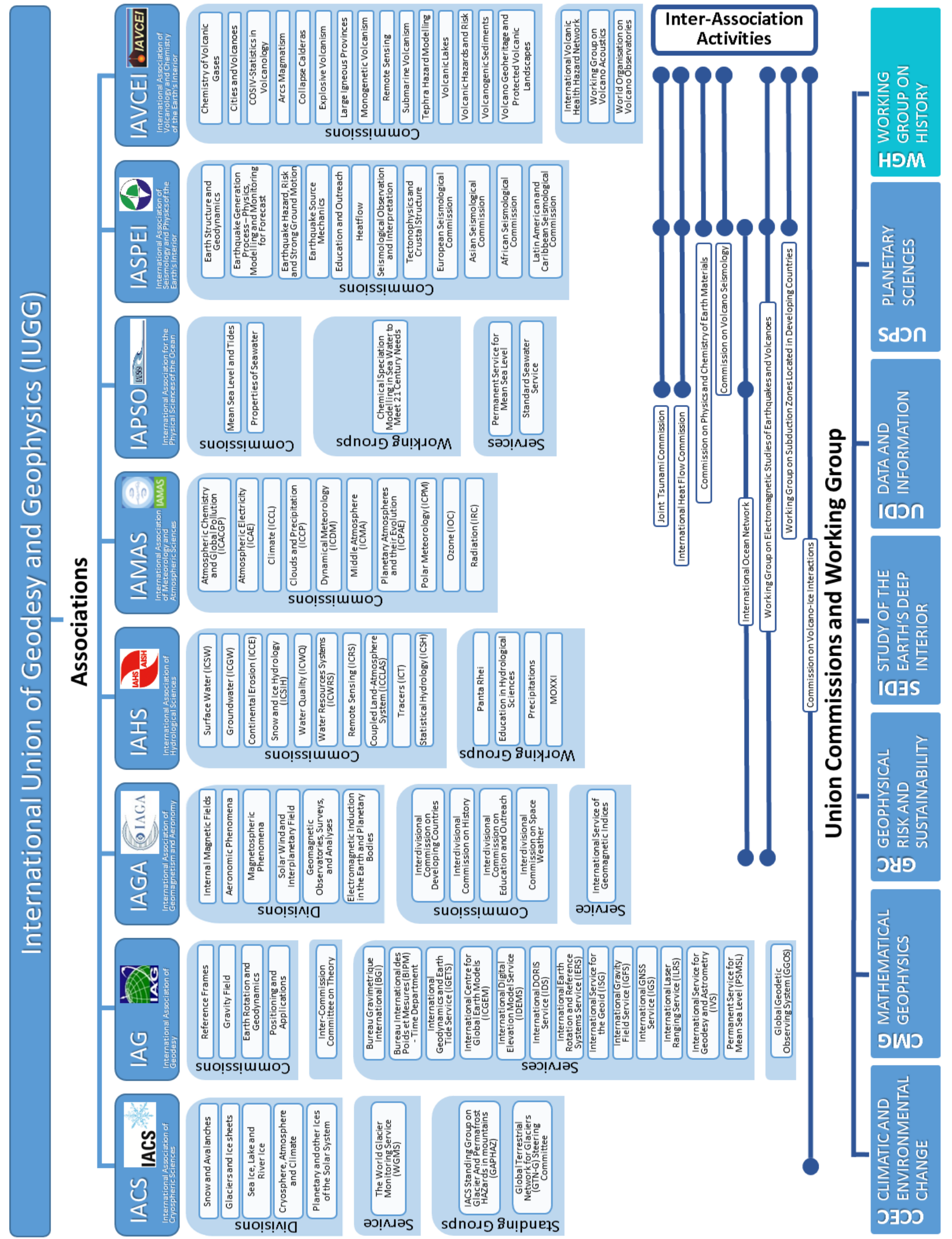

Figure 1. Organisational structure of the IUGG (designed by F. Kuglitsch). 
of several major disciplines of the IUGG. Historically, the original proposal for the name of the union was the International Geophysical Union; however, the IRC at its preliminary meeting in Paris in May 1919 adopted the expanded name of the union based on a motion of the representative of Italy (Bauer, 1919). The motivation of the Italian representative is unknown; it could be based on the fact that geodesy in the beginning of the 20th century positioned itself as a branch of mathematical rather than physical sciences, and this might be a reason why geodesy was considered separately from all other physical disciplines of the IUGG at the time of the union's establishment.

\subsection{Structure}

To understand how the union operates, we should look at the IUGG structure composed of eight international semiautonomous scientific associations promoting specific discipline(s) of geoscience, which is their raison d'être: the International Association of Cryospheric Sciences (IACS), the International Association of Geodesy (IAG), the International Association of Geomagnetism and Aeronomy (IAGA), the International Association of Hydrological Sciences (IAHS), the International Association of Meteorology and Atmospheric Sciences (IAMAS), the International Association for the Physical Sciences of the Oceans (IAPSO), the International Association of Seismology and Physics of the Earth's Interior (IASPEI), and the International Association of Volcanology and Chemistry of the Earth's Interior (IAVCEI). Within its own discipline(s), each association is responsible for determining its own research programmes and for supporting the activities of its own component parts. The IUGG can be considered as the "roof of the scientific colonnade" supported by the eight strong "pillars" that are union associations. At present, the IUGG and its associations operate through more than 110 scientific divisions, commissions, committees, working groups (WGs), and services (Fig. 1). Similarly, other geounions operate via their internal groupings. Some geounions have established joint WGs, such as the IAU-IAG/IUGG WG on the Theory of Earth Rotation and Validation, or URSI-IAGA/IUGG WG on Very Low/Extremely Low Frequency (VLF/ELF) Remote Sensing of the Ionosphere and Magnetosphere. It should be noted that scientific groups and sub-groups of geounions are quite productive, as small groups share common interests and usually act on shared objectives (Olson, 1965).

\subsection{Assemblies}

Since 1922 IUGG has held general assemblies (now every 4 years), which consist of an open scientific assembly, meetings of the delegates of member countries, and business meetings. Similarly, other geounions hold their general assemblies (or congresses) with a periodicity of 3 or 4 years. IUGG associations (either one association alone or jointly with other associations) convene scientific assemblies in-between IUGG general assemblies. At scientific assemblies, scientists can discuss their respective methodologies, results, and hypotheses, and initiate, plan, and review collaborative research projects. All the assemblies are intended to be particularly helpful to early career scientists and scientists from developing countries.

\subsection{Products}

IUGG associations have been working to set global standards for research and agree on definitions, equations, and algorithms. Among recent examples of scientific standards are the International Classification for Seasonal Snow on the Ground (Fierz et al., 2009), the International Terrestrial Reference Frame (ITRF, 2014), the International Geomagnetic Reference Field (IGRF; Thébault et al., 2015), the International Thermodynamic Equation of Seawater (IOC-SCORIAPSO, 2010), the Manual of Seismological Observatory Practice (Bormann, 2012), and the Guidelines for Professional Interaction During Volcanic Crises (IAVCEI Subcommittee for Crisis Protocols, 1999). In particular, a terrestrial reference frame provides a realisation (i.e. a set of coordinates of some points located on the Earth's surface) to the International Terrestrial Reference System, a world spatial reference system co-rotating with the Earth in its diurnal motion in space. World navigation systems are referenced either to a specific ITRF realisation or to their own coordinate systems, which are then referenced to an ITRF realisation. The IGRF is a series of mathematical models of the Earth's main magnetic field and its annual rate of change and used widely in studies of the Earth's deep interior and its lithosphere, ionosphere, and magnetosphere. The IGRF is the product of a collaborative effort between magnetic field modellers and the institutes involved in collecting and disseminating magnetic field data from satellites and from observatories and surveys around the world. The GeoID, an inclinometer installed on everyone's smartphones, involves IGRF solutions primarily used in mineral and hydrocarbon exploration.

Setting scientific standards has also been an important activity of other geounions. The IUGS International Commission on Stratigraphy sets standards for the fundamental scale for expressing the history of the Earth, namely, the commission precisely defines the global stratigraphic units of the International Chronostratigraphic Chart (Cohen et al., 2013). IAU develops fundamental standards for celestial and terrestrial reference systems/frames and the transformations among them; precession-nutation models; star catalogues; planetary system nomenclature; ephemerides of solar system bodies; and special and general relativistic models for time and space; and others. 


\subsection{Services}

IUGG associations set up and oversee geodetic and geophysical services; similarly, IAU and URSI act with respect to astronomical and other services. For example, the IAG established an observing system - the Global Geodetic Observing System (GGOS) - which works with the IAG's international services to provide the geodetic infrastructure necessary for monitoring the Earth system and for global change research. The GGOS provides the basis for defining and maintaining a stable, accurate and global reference frame, and hence it is crucial for all Earth observations and practical applications (Plag and Pearlman, 2009). The internationally driven services and products of IUGG associations are absolutely unique: they could not be done by any governmental organisation even though operations of the services depend on national funding. "The Associations should exist for these products alone, if for no other reason", said J. A. Joselyn, former IUGG Secretary General (personal communication, 2014).

\subsection{National membership}

In 1919 the International Research Council and the scientific unions under its umbrella were formed by national academies, and since that time the membership of the ICSU and its unions, including the IUGG, has been national and composed of principal national academies, research councils, and major university or governmental agencies. National members play an important role in the life of the IUGG as well as of other international geoscientific unions. IUGG national committees set up by national members organise IUGG-related activities in their countries. Many scientists participate in union activities through these national committees and represent their country at IUGG General Assemblies.

About 100 countries have been IUGG members since 1919. Some countries dropped their membership for different reasons, but often because of financial problems experienced by their scientific institution adhering to the union. For example, in developed industrial countries, a tendency of reducing subscription dues to international scientific unions seems to be associated with a general tendency of governments to reduce funding to national agencies and academies, with a funding prioritisation in the member organisations, and, in some cases, with a lack of understanding of the current role in and the added value of the unions to modern scientific development. In less affluent countries, there is either no critical mass of scientists to share the mission and major purposes of international unions, or there are severe political, economic, and financial issues preventing the countries becoming regular members of the union. In 2012, the Royal Society (the UK principal science academy adhering to many scientific unions of the ICSU) introduced a programme providing financial assistance to African countries to become a member of international scientific unions. The Royal Society covered a 3-year membership subscription for the countries, which expressed their interest and reported annually to the society on their activities in the union. Despite several international unions, including the IUGG, gaining a financial benefit from the programme, this initiative was not of much success. For example, the IUGG welcomed three new regular members from African countries for a few years, but none could maintain their status later.

There is the IUGG-specific problem in increasing national participation, the so-called "depth versus participation" dilemma (Bernauer et al., 2014): in applications to international scientific unions this dilemma can imply that the unions based on a single scientific subject can attract more countries as a member than those based on many subjects. As a union of eight international associations dealing with specific geoscience subjects, not many countries (compared to the number of nations in the UN) have significant expertise in all or even several IUGG scientific topics. For example, geodesy and hydrology are well developed in almost all countries of the world, but studies on the cryosphere or volcanoes are preferentially carried out in mountain/polar or active volcano regions. Meanwhile, to be eligible for union membership, a country should be involved in all or at least several scientific topics related to the union associations. This is a severe restriction, especially for less affluent countries, where only one or two IUGG scientific topics might be well supported by national programmes. In future, the IUGG should revisit its national membership to allow more countries to participate, e.g. by an inclusion of positive incentives to promote international cooperation (Bernauer et al., 2014).

Although the IUGG has no individual membership (individual membership programmes exist in some of the IUGG associations, such as IAG, IAHS, and IAVCEI, and in some geounions, e.g. in IAU), all scientists, not only those from member countries, can participate in the union's activities. This gives scientists from across the world the advantage of close cooperation, the opportunity to share data, and recurrent easy opportunities for open scientific discussion.

\subsection{Scientific and outreach programmes}

The IUGG has initiated and/or supported collaborative efforts that have led to highly productive worldwide interdisciplinary research and outreach programmes. The following major research programmes should be mentioned: the International Project on the Upper Mantle of the Earth (19641970), which continued as the Geodynamics Project until 1979; the International Hydrological Decade (1965-1974); the Global Atmospheric Research Programme (1967-1980); the International Geosphere-Biosphere Programme (19872015, merged with the Future Earth programme); the World Climate Research Programme (WCRP, 1980-present); and the International Lithosphere Program (ILP, 1980-present). In particular, the ILP was established as the Inter-Union 
Commission on the Lithosphere by the ICSU at the request of the IUGS and the IUGG, and in 2005 the ILP became a joint programme of the two geounions. The ILP promotes studies of the nature, dynamics, origin, and evolution of the lithosphere, paying special attention to the continents and their margins. It has established international multidisciplinary projects and working groups to pursue specific research in contemporary dynamics, shallow and deep processes, continental lithosphere, ocean lithosphere, and global change.

One of the most important developments in the IUGG in the post-WWII period was the follow-up to a proposal that the 75th anniversary of the First International Polar Year (1882-1883) should be commemorated by organising a similar venture in 1957. The IUGG urged the ICSU to invite the WMO to this activity, and the WMO accepted the invitation in 1951 and suggested extending the scope of the international year from the polar regions to cover relevant geophysical phenomena all over the world. In 1952 the ICSU supported the proposal and agreed to name the year the International Geophysical Year (IGY, 1957-1958; Davies, 1990). The IGY has a special place in the history of international scientific cooperation of the 20th century (Greenaway, 1996; Launius et al., 2010). "The spectacularly successful International Geophysical Year, run by the International Union of Geodesy and Geophysics, had received acclaim from the scientific world at large" (Harrison, 1978). The IGY was a remarkable project not only because of its outstanding accomplishments and the involvements of thousands of scientists, who contributed to the IGY success, but also because the year gave rise to several major international initiatives. Many distinguished geophysicists contributed to the initiation and promotion of this international year, among them Sydney Chapman (IUGG President, 1951-1954), Marcel Nicolet (IAGA President 1963-1967), Lloyd Berkner (URSI President 1957-1960), Vladimir Beloussov (IUGG President 1960-1963), and Jean Coulomb (IUGG President 1967-1971), just to mention a few prominent ones. The scientific legacy of the IGY includes the discovery of the Van Allen radiation belts encircling the Earth, the first estimation of the mass of Antarctica's ice sheet, the understanding of seafloor spreading and lithospheric plate tectonics, the understanding of anthropogenic contribution to climatic change, and, of course, the beginning of intensive space exploration by artificial satellites (Sputnik-1, the first artificial Earth-orbiting satellite, was launched on 7 October 1957 during the IGY).

By 2007, four programmes had been established to commemorate the 50th IGY anniversary: the International Polar Year (IPY, 2007-2008) led by the ICSU and the WMO, the International Heliophysical Year (IHY, 2007-2008), the Electronic Geophysical Year (eGY, 2007-2008), both led by the IAGA/IUGG, and the International Year of Planet Earth (IYPE, 2007-2010) led by the IUGS. These programmes have set a model for international, interdisciplinary and transdisciplinary cooperation.
The IUGG was involved in the establishment, development and support of interdisciplinary scientific bodies of the ICSU, especially those in which Earth sciences have a role to play. Together with several geounions, the IUGG had an important role in establishing the Federation of Astronomical and Geophysical Data Analysis Services in 1956, the Scientific Committee on Oceanic Research in 1957, the Scientific Committee on Antarctic Research in 1958, the Committee on Space Research in 1958, the Scientific Committee on Solar-Terrestrial Physics in 1966, the Scientific Committee on Problems of the Environment in 1969, the Special Committee for the International Decade for Natural Disaster Reduction in 1990 (Greenaway, 1996), the IRDR and the World Data System (WDS) in 2008.

Other geounions have also been active in developing and promoting scientific and outreach programmes. For example, the International Geoscience Programme (IGCP) is a successful example of scientific cooperation between the IUGS and the U.N. Educational, Scientific and Cultural Organisation (UNESCO), bringing together geoscientists from economically less and more developed nations. Over more than 40 years, tens of thousands of scientists have actively participated in IGCP projects, and for many of them the programme has been the gateway to a successful career in and beyond geoscience. The IGCP has also been responsible for some major geoscientific programmes of ground-breaking international standards (Derbyshire, 2012). In 2015 UNESCO decided to merge the IGCP with the Global Geoparks Programme to create the International Geoscience and Geopark Programme to "reflect the societal challenges of Earth sciences"1.

\subsection{Cooperation with intergovernmental organisations}

Since 1919, the IUGG through IAMAS has cooperated with the International Meteorological Organization (IMO), which was established in 1873 with the basic goal of weather information exchange between the countries. For example, in 1936 IAMAS awarded a grant to the IMO to purchase radiosondes and to enable some national meteorological services to take part in an investigation of the upper atmosphere. The grant was made on the condition that the countries concerned would carry out the observational programme as laid down by the IMO (Davies, 1990). In 1950 the IMO was superseded by the WMO to coordinate and promote the UN activities in meteorology, including weather and climate, operational hydrology, and related geophysical sciences. The relations between the WMO and the IUGG were formalised by the signing of a working agreement in 1953. The substance of this agreement was that the IUGG is recognised by the WMO as the international forum for the advancement of meteorology, while the WMO is recognised by the IUGG as having the primary responsibility for the international organ-

\footnotetext{
${ }^{1}$ http://www.unesco.org/new/en/natural-sciences/environment
} 
isation of meteorology. The WMO and IUGG agreed to keep each other "advised of all developments and projected activities" within the WMO and IUGG fields of interest (WMO, 2002). Since 1953 the IUGG has been developing a cooperation with the WMO in meteorology (via IAMAS), hydrology (IAHS), the cryosphere (IACS), space weather (IAGA), and volcanology (IAVCEI). In particular, after the 2010 Eyjafjallajökull volcano eruption and at the request of the International Civil Aviation Organisation (ICAO), the WMO and IUGG established a joint Volcanic Ash Scientific Advisory Group (VASAG) to provide scientific advice on volcanic ash to civil aviation. Representatives of the IUGG have been invited to WMO Executive Congresses, and representatives of the WMO to IUGG General Assemblies.

Another example of long-lasting productive cooperation of the IUGG with UN agencies is a collaboration with UNESCO and its scientific programmes. The IUGG has been cooperating with the Intergovernmental Oceanographic Commission (IOC) and the International Hydrological Programme (IHP) through the IAPSO and the IAHS since the establishment of the bodies in 1960 and in 1975, respectively. For example, the IAHS established the International Hydrology Prize in 1981 in cooperation with the IHP and the WMO to award distinguished scientists who have made an outstanding contribution to hydrological science. For years, the IUGG via the IASPEI and the IAVCEI cooperated with the UNESCO Earth Science division in the framework of its programmes related to geohazards and risks. Representing many disciplines of Earth and space sciences, the IUGG has been, and continues to be, involved in projects and programmes related to climatic and environmental changes and their impacts, including periodic scientific assessments by the Intergovernmental Panel on Climate Change (IPCC). Many IUGG experts shared the Nobel Peace Prize 2007 with the IPCC for "efforts to build up and disseminate greater knowledge about man-made climate change, and to lay the foundations for the measures that are needed to counteract such change" (from the Nobel Peace Prize 2007 citation).

Since the inception of the IRDR scientific programme, cosponsored by the ICSU, the International Social Sciences Council (ISSC), and the UN Office for Disaster Risk Reduction (UNISDR), the IUGG and other geounions have been working closely with the IRDR Scientific Committee on problems related to natural hazards and disaster risks (Cutter et al., 2015; Ismail-Zadeh and Cutter, 2015). The IUGS cooperates with the UNESCO Earth Sciences and Geohazard Risks section in the framework of the International Geoscience and Geoparks programme. The IAG/IUGG, ICA, IGU, and ISPRS have been cooperating with the UN Office for Outer Space Affairs in the framework of disaster risk management (the UN-SPIDER programme).

Since the establishment of the Preparatory Commission for the Comprehensive Nuclear-Test-Ban Treaty Organisation (CTBTO), the IUGG has been cooperating with this organisation on several scientific topics; IASPEI, IAPSO, and
IAMAS experts have been involved in the activities of the CTBTO International Monitoring System, a network of stations and laboratories established worldwide to monitor the underground, underwater and the atmosphere for any sign of a nuclear explosion; the IUGG also participates in science programme committees for the CTBTO's Science \& Technology conferences. The IUGG contributes to the activities of the Group on Earth Observations (GEO) via the GGOS, a part of the IAG. The IUGG provides advice to the International Telecommunication Union (ITU) on international timescales, and works with the U.N. Environmental Programme (UNEP) on topics related to weather, climate, and food security. The IAG/IUGG has cooperated closely with the UNCE-GGIM's Working Group on Global Geodetic Reference Frame on global geospatial information. This led to the adoption of a resolution, "A Global Geodetic Reference Frame for Sustainable Development", by the UN General Assembly in 2015. Independent non-governmental scientific advice to intergovernmental institutions (e.g. UNESCO and the WMO) by the IUGG and other geounions has been providing benefits for all parties as well as for science policy.

"Science policy" is an essential component of IUGG and geounion activities related to dissemination of scientific knowledge among the countries and the public. Let me mention one of the recent examples of science policy work on disaster risk reduction led by the IUGG in close cooperation with geounions. Risk assessments could contribute to enhancement of the knowledge on disaster risk at global, regional, and local levels, and to the awareness of the people living with risk. The scientific assessments help policymakers develop a policy for significant reduction of disasters. In 2011 the IUGG proposed to the ICSU to start negotiations on setting up an international/intergovernmental body for disaster risk assessment. The 31st ICSU General Assembly urged its members to work closely with UNISDR and other international and intergovernmental bodies to integrate scientific knowledge on disaster risks and risk assessments into decision-making and actions and invited ICSU national members to actively encourage their governments to support the proposed intergovernmental disaster risk assessment process (ICSU, 2014). An ad hoc group of experts on disaster risk reduction set up by the ICSU with ISSC participation worked on these issues and prepared a synthesis report on disaster risk science and risk assessments, which called for a multidisciplinary unified risk assessment. The report's summary for policymakers was distributed to representatives of national governments attending the UN World Conference on Disaster Risk Reduction held in March 2015 in Sendai, Japan (Ismail-Zadeh and Cutter, 2015).

Many geounions, including the IUGG, issue policy statements and special resolutions. For example, after the Eyjafjallajökull, Iceland, volcanic crises in 2010, the IUGG issued two statements, Volcanic Ash Clouds and Volcanological and Meteorological Support for Volcanic Ash Monitoring (IUGG, 2010a, b). The policy statements called on nations to 
recognise the importance of volcanic ash monitoring. Soon after, the VASAG was established. As a response to the indictment of the Italian geoscientists involved in the scientific judgement regarding the 2009 L'Aquila earthquake, the IUGG issued a statement, Freedom to Conduct Science and Responsibilities of Scientists, which highlighted that "scientists have an individual responsibility to conduct their work with honesty, integrity, openness and respect, and a collective responsibility to maximize the benefit and minimize the misuse of science for society" (IUGG, 2010c).

\section{Professional societies of geoscientists and geounions: similarities and differences}

Many professional societies of geoscientists have grown up during the 20th century, involving many thousands of scientists in countries around the world. The mission of professional societies is primarily educational and informational, and their main activities include publication of professional journals and books, development of professional excellence and promotion of honour programmes, organisation of scientific meetings, and production of science policy statements to raise public and political awareness of Earth and space studies. These societies are well known among scientists and students because they produce scientific journals and books and organise major annual meetings where students and scientists can present their recent scientific findings. In this section, the development of three professional societies of geoscientists the American Geophysical Union (AGU), the European Geosciences Union (EGU), and the Asia Oceania Geosciences Society (AOGS) - are briefly analysed.

The AGU traces its history back to 1919, when the American section of the IUGG was formed (Wood, 1919a, b). The AGU introduced an individual membership in the 1930s, when the restriction on AGU membership was lifted (Graedel, 1999). In the middle of the 1940s, under the pressure of the individual membership's growth, AGU decided to change the union management by introducing full-time professional staff members to help the union's officers in daily management. In 1944 Waldo Smith was hired as the first AGU Executive Secretary, and after his retirement in 1970, Fred Spilhaus became the Executive Director until his retirement in 2009. These two persons together with hundreds of American geoscientists shaped the present AGU, which is today one of the leading North American professional societies of geoscientists, with significant international participation: of its more than 60000 members, about $35 \%$ of them are from outside the USA and Canada (AGU, 2012). The AGU has developed an outstanding scientific meeting programme, with its annual premier Fall Meeting attracting more than 20000 scientists from North America and from around the world. Over 35 years the AGU has also held well-known Chapman topical conferences attracting several hundred scientists. Also, the AGU has a distinguished pub- lication programme of premier geophysical journals such as the Journal of Geophysical Research, Geophysical Research Letters, and Reviews of Geophysics, as well as a book series. Since 1939, the AGU has been recognising excellence in the geosciences and awarding scientists for their contribution to Earth and space sciences (Ball et al., 2015). The society also runs a career programme offering career advice and job data, and administers programmes to provide travel and research support for students. In 2008, the AGU started to reshape its structure and activities. One of the essential components of the AGU reorganisation is the consideration of societal implications of scientific discoveries. The AGU established new focus groups (e.g. Global Environmental Change, Natural Hazards, Societal Impact and Policy Sciences), interdisciplinary journals (such as Earth's Future) with a link to social sciences, Science Policy conferences, and the Thriving Earth Exchange project, which aims to connect scientists with those who seek solutions and those who fund research.

The EGU was established through the merger of the European Geophysical Society (EGS) and the European Union of Geosciences (EUG) in 2002. The EGS was founded in 1971 by distinguished European geophysicists with AGU assistance and replicated (to some extent) AGU activities in Europe. In 1981, the AGU and the EGS agreed to copublish Tectonics, and in 1989, they agreed to share an office in Europe, the European Office of the AGU. The EUG was founded in 1981 with the goal of promoting cooperation between scientists in all fields of the Earth and Planetary Sciences through general scientific meetings and journal publications. An EGS-AGU-EUG Joint Assembly was held in Nice in 2003 with about 11000 participants. The winding down of the two European professional societies (EUG and EGS) was completed by the end of 2003, and the first EGU general assembly was held in 2004. Today the EGU is the most distinguished geoscience society in Europe with its premier annual general assemblies in Vienna, Austria, which gather more than 12000 geoscientists. The EGU develops conference series targeted at a specific disciplinary or interdisciplinary group. The EGU, through Copernicus Publications, publishes peer-reviewed open-access journals covering various planetary and space sciences topics. Like the AGU, the EGU has also developed a broad honour and recognition programme and presents awards annually to scientists for their contributions to the geosciences.

The AOGS is a young and most dynamic geoscience society in Asia and Oceania bringing together geoscientists from the region and from other parts of the world. It was established in 2003 to promote geophysical science for the benefit of humanity in the region. The AOGS organises annual general meetings in different countries of the Asian and Oceanic regions, sometimes jointly with other societies, e.g. with the AGU in 2012. The society developed a recognition programme including the Afford Medal for outstanding achievements in geosciences and unselfish cooperation and leadership in Asia and Oceania, and distinguished lecture se- 
Table 1. The income and expenditure of the AGU and IUGG in 2012 (USD).

\begin{tabular}{lrr}
\hline Revenue & AGU & \multicolumn{1}{c}{ IUGG $^{2}$} \\
\hline Member dues & 925772 & 429172 \\
Grants & 2121529 & 25707 \\
Meetings & 9218238 & 0 \\
Publications & 33649114 & 0 \\
Other & 1689744 & 8361 \\
Total & 47604397 & 463240 \\
Expenditures & 40636061 & 508852 \\
\hline
\end{tabular}

${ }^{1}$ AGU (2012); ${ }^{2}$ IUGG (2012).

ries, including the Afford distinguished lectures. The AOGS and Springer jointly publish Geoscience Letters.

Similarities and major differences in activities of geounions and professional societies are reviewed below, covering the topics of publications, scientific programmes and meetings, education and capacity building, early career scientists, membership, management, and finance.

\subsection{Publications}

The AGU and EGU publication programmes are scientifically thorough and well known among the geoscience community. Apart from the importance of research publications in science promotion, the business is very profitable: at least until 2012, the AGU's major source of income (about $70 \%$ ) came from the publication of journals and books (see Table 1), which gives the union significant flexibility in arranging various activities. Since its inception, the IUGG has not considered scientific publishing among its major activities. The IUGG published, jointly with the AGU, a book series until 2007, and agreed later with the Cambridge University Press to produce special publications on interdisciplinary and multidisciplinary topics in geophysical sciences. Several IUGG associations have developed their publication programmes: the Journal of Geodesy (by the IAG), the Hydrological Sciences Journal (by the IAHS), and the Bulletin of Volcanology (by the IAVCEI). Several geounions have also developed their publication programme, and their journals are well known in the relevant communities, such as the IAU Special Publications, the INQUA's Quaternary International, the ISPRS Journal of Photogrammetry and Remote Sensing, the IUGS's Episodes, and Radio Science published by the AGU and URSI.

\subsection{Scientific meetings}

Geounions and professional societies of geoscientists have been contributing to the promotion of science via scientific annual meetings, assemblies, conferences, and symposia they organised or co-sponsored. For societies of geoscientists, these activities are of primary importance. An- nual meetings of the AGU and EGU present examples of a rich scientific programme and effective meeting management. The latter point is associated with the fact that the AGU and EGU annual meetings have been held in the San Francisco Moscone Center and in the Austria Center Vienna, respectively, for many years. IUGG general assemblies or association scientific assemblies as well as assemblies and congresses of geounions are normally held at an interval of 2 or 3 years in different places of the world. It makes organisation and management of the meetings complicated, depending on the local organisers, their capacity and resources.

\subsection{Education and capacity building}

The development of advanced knowledge and skills of students and scientists through learning experience, study, instruction, and practical work has always been an essential component of the science education activities of international unions as well as professional societies. Because geoscience disciplines require careful observations made in standardised ways, training is a common educational strategy. For years, the IUGG and its associations have organised or cosponsored dozens of scientific workshops and symposia annually in countries around the globe. These meetings have a strong educational aspect: young and otherwise financially disadvantaged scientists, who cannot usually travel to international meetings, can gain exposure and present papers at professional meetings (Fig. 2).

The IAU developed a long-term educational plan, "Astronomy for Development", focusing on the use of astronomy to stimulate capacity building and further sustainable development. The IGU promotes and coordinates geographical and environmental education globally, and co-sponsors geography olympiads. The IUGS Commission on Geoscience Education, Training and Technology Transfer (COGE) develops science education programmes to assist industrialised and less affluent countries to maintain, expand or introduce better Earth science education, outreach and technology transfer within their countries.

The AGU developed the Bright Students Training as Research Scientists project to involve middle and high school students in the Earth and space sciences via participation in after-school and summer research experiences (Asher and Saltzman, 2012). Since 2003, the EGU has organised Geophysical Information for Teachers (GIFT) workshops at its general assemblies. These programmes offer teachers of primary schools to high schools the opportunity to upgrade their knowledge on geoscience topics, to hear about the latest geoscience discoveries, and to shorten the time between new discoveries and textbook information. The AGU has collaborated with the National Earth Science Teachers' Association since 2011 to run GIFT workshops at its Fall Meetings. Although geounions and professional societies of geoscientists dedicate time and efforts to science policy and capacity building, their geographical coverage is different: more inter- 


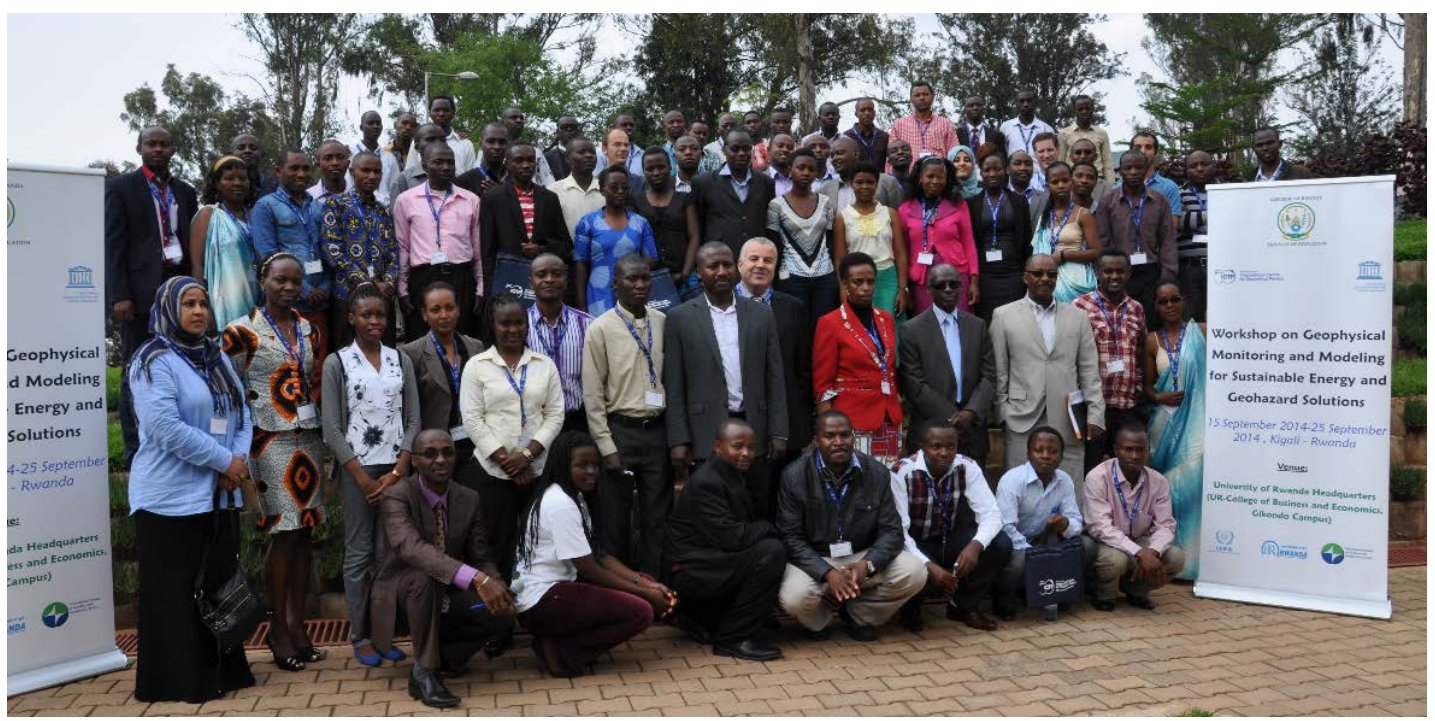

Figure 2. Participants of the workshop on Geophysical Monitoring and Modeling for Sustainable Energy and Geohazard Solutions, cosponsored by the ICTP, the IUGG and the University of Rwanda, Kigali, Rwanda, 15-25 September 2014. The event was attended by 77 participants from 19 different countries (photo by A. Aoudia).

national activities with an emphasis on the developing world versus more country- and region-specific activities.

\subsection{Early career scientists}

When you ask geoscience students and early career scientists whether they know of the AGU, EGU or AOGS, many of them answer affirmatively, as they often are individual members of the societies and have participated in their annual meetings and/or published research results in their journals. Only a few know more about other activities of the AGU and EGU. If you ask the same people whether they know of the IUGG, most of them will respond negatively, although some of them have heard of or participated in the meetings or even published in journals of the IUGG associations. Why does the difference in awareness exist?

Historically the IUGG's activities have been based on the work of international experts from IUGG/association scientific divisions, commissions, committees, working groups, services, etc. Students and even early career scientists have been rarely involved in these scientific groupings. There are several reasons for that. Young scientists are actively building their professional careers and often have no time to dedicate to promotion of science, although some of them promote science through social media. They are not well linked to international networks and have less experience in international collaboration than their older colleagues. The IUGG/associations scientific assemblies are held biennially (compared to annual AGU, AOGS, and EGU meetings), and this makes IUGG assemblies less known among graduate students. For those young people who know about IUGG, the union structure and national membership could become other complications in terms of involvement in the union's activities. Therefore, the IUGG as well as other geounions should develop a programme for greater involvement of early career scientists in the union's activities.

Early career scientists can easily understand the benefit of being an individual member of professional societies (e.g. AGU or EGU), but not the benefit of geounions (e.g. IUGG). To improve the situation regarding the involvement of early career scientists, the IUGG established in 2003 a series of union symposia held at IUGG General Assemblies and dedicated to early career scientists and their vision of the future. In 2013, the IUGG approved the Early Career Scientist Award programme to recognise scientific achievements of young scientists. Moreover, the IUGG and geounions help several international networks of early career scientists to promote science, among them, the Association of Polar Early Career Scientists (APECS) and the Young Earth Scientists (YES) network. More work should be done to attract the best early career scientists to contribute to geounion activities.

\subsection{Membership}

One of the main differences between geounions and professional societies is in their membership structure. Memberships of the geounions are national. A principal national scientific body belonging to an international union pays annual union membership dues, which are primarily determined by the country's economic indicators and scientific activities. All scientists of member countries can then participate in any activity of the union, can vote and can be elected to various offices. The national committees of member countries interact with scientific experts in their countries, promote them in 
unions, generate discussion on various important scientific issues on the global international context, coordinate activities of national and international programmes, etc.

Professional societies normally introduce an individual membership fee, with a reduced fee paid by students, retired persons, and sometimes by the scientists living in less affluent countries. An individual membership is attractive for scientists, especially from economically well-developed countries, because of its benefits, such as reduced registration fees for annual meetings, reduced costs for books and annual journal subscriptions, and involvement in the organisation of scientific sessions. Although the membership of professional societies is international and open to any scientist in the world, the societies reflect the interests of the geoscience communities of North America, Europe and Asia/Oceania, respectively, and are governed primarily by regional scientists, occasionally with participation by a few people from other parts of the world.

Considering the attractiveness of individual membership, should international scientific unions abandon national membership and replace it with individual membership? Advocates of this proposal believe that this will lead to a democratisation of the unions and bring significant visibility to the unions. The proposal has some merit in terms of visibility, but a direct implementation of this proposal may lead to a starvation of the unions because of funding decline and strong competition with well-established local professional societies of geoscientists. Just an example in support of this statement: the AGU's income from member dues in 2012 was about $2 \%$ of the union's overall annual income. An income from individual membership fees does not constitute the basis for the budgeted activities of professional societies, but the income from publications and meetings does. Meanwhile, the major income of the geounions comes from the membership dues paid by national members and not from other sources (see Table 1 for a comparison between AGU and IUGG income categories). Therefore, geounions may try a combined national and individual membership approach, similar to that developed by the IAU. Individual members from member countries would pay no fee, but can donate to geounions or pay a small fee to get reduced journal subscription and/or conference registration fees, as is the case for some IUGG associations.

\subsection{Management and finance}

For efficient administrative and technical operations, several geounions have set up their secretariat hosted by one of their member countries. The secretariats are staffed by a few people only. The AGU and the EGU have their offices staffed by a number of employees responsible for specific parts of the overall management of the professional societies. Compared to the AGU (the union's budget was USD 41 million in 2012), the geounions (e.g. the IUGG's budget was USD 0.51 million in the same year) operate with a low budget (see Table 1 for a comparison between the AGU's and IUGG's income and expenditures). The income of international unions consists essentially of the membership dues paid by national members. A significant part of their annual income comes from economically developed countries, primarily from the countries in North America, Europe, and Japan. The diversity of income streams of professional societies, with a significant amount of revenue from meetings and publications, allows the societies to be more flexible in their programme developments.

\subsection{Concluding remarks}

Based on the analysis and comparison of the activities of professional societies of geoscientists and geounions, a conclusion can be drawn that geounions as well as professional societies promote Earth and space sciences and contribute to the betterment of science using complementary (with some inherent overlapping) approaches. Whereas the principal concerns of national and regional professional societies are scientific meetings and publications as the major tools for promotion of science, international scientific unions also attach significant value to initiation and promotion of international scientific programmes, development of geoscientific services and products, and international unselfish research cooperation. Geounions link geoscientists belonging to professional societies via scientific and outreach programmes and services of geounions or interdisciplinary/inter-union groupings to intergovernmental programmes and to international decision-making.

\section{Added value and social significance of international scientific unions}

Perhaps the earliest reasoning behind the existence of associations can be found in the work by Aristotle, Nicomachean Ethics $(\sim 340 \mathrm{BC})$. In particular, Aristotle wrote that "Travellers ... associate together ... to procure some of their necessary supplies. ... (T)he political association too, it is believed, was originally formed, and continues to be maintained, for the advantage of its members" (chap. VIII, Sect. 1160a.1.; Rackham, 1926). The same applies to international scientific unions. They exist to promote scientific research internationally for the advantage of their national members, scientists, and society in general. To explain the role of international scientific unions in the modern world of science, it is important to analyse the added value of the unions to promotion of science based on the analysis of their contribution to science promotion in the past.

\subsection{Scientific and outreach programmes}

Geounions have been involved in all stages of programme development, including their initiation and promotion (e.g. ILP and IGCP). They are instrumental in keeping national 
academies and national agencies informed about the latest scientific initiatives and programmes. Geounions have initiated scientific and outreach programmes and, with the support of the ICSU and intergovernmental bodies, implement the programmes at national, regional, and global levels (e.g. the 2007-2008 EGY, the 2007-2008 IYPE, the 2009 International Astronomical Year, the 2015 International Year of Soil, and the 2016 International Year of Global Understanding). In cooperation with national committees, they keep nations informed about important scientific results and availability of scientific standards and global measurements (such as geodetic measurement by the global navigation satellite system). Therefore, the role of international scientific unions is to improve the awareness of scientific knowledge among nations, politicians, and society.

\subsection{Science for society}

The social significance of geounions consists of the promotion of science to benefit humanity. For example, in the middle of the 20th century, the impacts of climatic and environmental changes were well understood by many experts involved in relevant studies and programmes of geounions and the ICSU (Weart, 2012). The experts proposed to establish a major scientific programme on climate, and after long debates, the WCRP was set up by the WMO and the ICSU in 1980 in order to "determine the predictability of climate and to determine the effect of human activities on climate" (from the WCRP mission statement). Later, experts of geounions involved in ICSU environmental programmes argued for periodic climatic change assessments, and contributed to the process of setting up the IPCC to help raise awareness of societies and politicians about climatic change (Bolin, 2007). One of the notable persons behind several major international environmental programmes was Bert Bolin (IUGG Bureau Member, 1963-1967): he was involved in setting up and in developing the Global Atmospheric Research Programme (Ashford, 1982), the WCRP, the International GeosphereBiosphere Programme (IGBP), and the IPCC, becoming the IPCC's first Chairman (1988-1997) (Rohde, 2013). This example shows a coherent link between geounions (in particular, the IUGG) via interdisciplinary bodies of the ICSU (such as the IGBP and the WCRP) to the intergovernmental organisations (like the IPCC) as well as a way of knowledge delivery from scientists to policymakers and society.

\subsection{Science and capacity building to the developing world}

Geounions have been playing a special role in bringing stateof-the-art science to less affluent countries of the world, especially after WWII. This is done primarily through workshops, summer schools, symposia and assemblies as well as scientific programmes and projects. The geounions encourage young scientists, particularly those from developing coun- tries, and nurture their participation as scientists and as leaders. They make research visible to the international scientific community, to governmental agencies, to industry, and to the general public through their capacity building and education activities. For many (especially developing) countries, international scientific unions offer more in return than the countries pay in dues. The return can be insight and knowledge, data, impact, grants, etc.

\subsection{Observational and data services}

Since the IGY, geounions (e.g. IAU, IUGG, and URSI) in cooperation with the WDS have been coordinating international geophysical, geodetic, radio, and astronomical services. These services include a wide range of observational (with outputs or products) and data (custodians of datasets, standards, etc.) services. Since 2005, geounions have cooperated with the intergovernmental GEO, providing scientific knowledge and expertise in data acquisitions, assessments, and modelling.

\subsection{Networking and infrastructure}

International unions promote networking of scientists and provide access for scientists to the best of modern science. International unions provide an infrastructure (e.g. various groupings inside geounions) which is very useful in many situations, for instance, when getting developing countries involved in scientific matters. International expert groups (e.g. commissions, committees, working groups) set up new scientific priorities and directions considering the needs of many nations and promote research topics of scientific and/or societal importance. They work to set standards for research.

\subsection{Cooperation}

Geounions cooperate with international and intergovernmental organisations in linking basic science to science for society and policymaking. Unions preserve a unique and essential space between professional societies of scientists and intergovernmental organisations and decision-makers. International unions stand for free movement of scientists as well as free circulation of scientific data and information, although the issues can be very political (e.g. visa restrictions prohibiting free movement of scientists) and sometimes do not depend on the position of scientists or scientific unions.

Finally, with very limited funding, geounions generate significant international activities around the world. Geounions play a crucial role in steering the minds of scientists in new research directions in Earth and space sciences and in promoting scientific research and cooperation, especially in basic research and in science for society. The scientific return from geounions (on a relatively small annual investment from national members in the form of membership dues) compared, for example, to funding a specific research project 
is rather big in terms of scientific impact, infrastructure, outreach, etc. It becomes increasingly important as the world becomes more globalised.

\section{Discussion and conclusion}

The geounions provide balanced, factual, and independent scientific information about the Earth and its space environment. Besides the knowledge, which satisfies the curiosity of the human beings related to the planet, where they live, and to the Moon, Sun, and stars, which they observe every day, the geounions provide more oriented knowledge, information, and guidelines on important society-relevant problems (working in such a way on science for the benefit of humanity). Among the problems they address are climatic variability and the contribution of $\mathrm{CO}_{2}$ emission to its change in order to save our planet for future generations; environmental pollution and its reduction in megacities to improve the quality of life; natural hazards (e.g. hurricanes, floods, earthquakes, landslides) and mitigation/prevention of disasters to save lives and infrastructure; weather, water, and soil conditions to assist farmers during harvests and provide other indispensable ecosystem services; mineral resources for future generations; clean water and its contamination to preserve and enhance human and ecosystem health; geodetic measurements to navigate airplanes, satellites and mobile phones; pollution of oceans and seas, biodiversity and food security; and many others. Geounions increase geoscience literacy through capacity building activities all over the world.

The landscape of geosciences is changing: we are witnesses of pressing challenges, e.g. the sprawl of towns and the growth of megacities, climatic and environmental change, ocean acidification and sea pollution, disasters due to natural and human-induced hazards and associated losses due to vulnerability of societies, unsustainable land use, and depletion and scarcity of mineral resources/water. Societal problems need an integrated, transdisciplinary scientific approach. Although scientific unions and professional societies have been promoting and should continue to foster fundamental science for new discoveries, they should also promote interdisciplinary/transdisciplinary and co-productive research as well as integrated and system analysis. Geounions should place an emphasis on scientific investigations for interventions, that is, to foster action-oriented solutions of societal problems (e.g. Showstack, 2015). The geounions may play a significant role in independent (non-governmental) scientific assessments of society-relevant urgent problems, such as environmental change, disaster risks, energy, the ocean and its seas, and water resources.

Does modern science need international nongovernmental organisations for its promotion? Can the national and regional organisations replace them? What would happen if international scientific unions disappear? Historically, the geounions were set up as a response to the need for cooperation between nations, as many aspects of geosciences required international involvement. Neither national nor regional professional societies can truly replace international unions, as their major concern is their own nation or geographical region.

Looking to the future of geoscience groupings, three possible scenarios can be drawn:

1. integration of geounions and professional societies of geoscientists;

2. reshaping of scientific priorities and structures of current geoscience organisations and their independent development in a cooperative way; and

3. competition between geounions and professional geoscience societies.

The first scenario could lead to a development of the International Geosciences Union (IGeoU) with major regional branches in Africa, Central and South America, Asia/Oceania, and North America/Europe and with major disciplinary and interdisciplinary associations. The IGeoU could then act as a scientific body (self-maintained financially) coordinating activities of its regional branches and its scientific associations. This should be preceded by convergence, integration, and final fusion of geounions on the one hand and convergence or alliance of national geoscience societies on the other hand. IGeoU could provide a full spectrum of services and benefits to its members: from scientific meetings and publications to involvements in the initiation, promotion, and implementation of national/regional/international scientific programmes, scientific specialised commissions and working groups, geoscientific services and outreach programmes linking science to society and national and international policy. Such an international organisation could become a single but strong voice of geosciences and promote science to benefit humanity in a more efficient way.

The second scenario is more conservative. International scientific unions as well as national and regional societies of geoscientists would continue their operations reshaping their structure and activities to meet modern scientific challenges. They establish/strengthen cooperation among them using a complementary rather than competitive approach. In the long term, this scenario may lead to a fusion of the geounions and professional societies of geoscientists (the first scenario or its modification).

The third scenario is negative for international cooperation and development. National and regional societies of geoscientists will continue to enhance their activities and to attract more and more scientists (especially those of younger generations) and promote national/regional policies encouraged by national governments or regional political structures (e.g. the European Union). Due to the short-sighted policies of some national scientific institutions, which provide the funds 
necessary for membership to the international unions, some developed countries may withdraw from membership of the unions or reduce the amount of their membership dues. In this case, the international unions will lose the ability to continue their operations and will cease to exist. The disappearance of international scientific unions would

i. lead to "nationalism" in science, which may lead, in its turn, to replacement of "science for peace" with "science for defence", to significant polarisation of the world, and to replacement of scientific openness with secrecy and control of scientific information (e.g. Doel and Needell, 1997; Doel et al., 2005);

ii. result in the disintegration of many important scientific programmes already established;

iii. harm (if not end) new international multidisciplinary programmes; and

iv. become destructive for the world's scientific development and cooperation, as many developing nations get involved in scientific programmes mostly via international programmes and through the activities of international scientific unions.

These scenarios describe the wide range of possibilities for future development of the geounions. The first and third scenarios are two end-member models, and it is likely that neither scenario could be realised in full. The author considers the second scenario to be more realistic, at least in the near future.

The role of international geoscientific unions in promoting scientific cooperation and fostering scientific development has been analysed in the paper using the historical overview, recent development and future projections. The major activities of the IUGG and other geounions over a century have been assessed. This paper contributes to knowledge on key geoscientific organisations (both geounions and professional societies of geoscientists), which promote Earth and space sciences using common and complementary tools.
The main conclusions emerging from the analysis and discussions in this paper can be summarised as follows.

- International geoscientific unions played a significant role in promotion of geoscience via international cooperation in the 20th century, and they still have the potential to do so in the 21 st century.

- Geounions have been playing an important regulatory role in geoscience, particularly in establishing the terms and conditions for international research cooperation, setting scientific standards and nomenclatures, and preparing universal tools, among other aspects. Geounions bring state-of-the-art science to less affluent countries through capacity building.

- Geounions link scientists via their scientific, educational and outreach programmes being initiated and developed by various groupings of the unions to programmes of intergovernmental organisations and assist in setting up international scientific agendas, policies, recommendations, and guidelines.

- Geounions should continue to foster fundamental geosciences, be involved in transdisciplinary co-produced research, and make use of science for society through international scientific cooperation. The application of geoscience to societal needs requires coordinated efforts between geounions and their cooperation with other stakeholders, including professional societies and intergovernmental organisations.

Knowledge and data on the Earth and its space environment gained through international research collaboration provide the information necessary for the discovery and responsible use of natural resources, sustainable management of the environment, and reduction of the impact of natural hazards. We should always remember that it is through international cooperation that scientists satisfy the world's curiosity about the Earth and the consequences of human activities. 
Appendix A: List of acronyms

ISPRS

AGU American Geophysical Union

AOGS Asia Oceania Geosciences Society

CTBTO Comprehensive Nuclear-Test-Ban

Treaty Organization

EGS European Geophysical Society

EGU European Geosciences Union

EGY Electronic Geophysical Year

EUG European Union of Geosciences

GEO Group on Earth Observation

GGOS Global Geodetic Observing System

GIFT Geophysical Information for Teachers

IAA International Association of Academies

IACS International Association of

Cryospheric Sciences

IAG International Association of Geodesy

IAGA International Association of

Geomagnetism and Aeronomy

IAHS International Association of

Hydrological Sciences

IAMAS International Association of

Meteorology and Atmospheric Sciences

IAPSO International Association for the

Physical Sciences of the Ocean

IASPEI International Association of

Seismology and Physics of the Earth's Interior

IAU International Astronomical Union

IAVCEI International Association of

Volcanology and Chemistry of

the Earth's Interior

ICA International Cartographical

Association

ISSC

ITC

ITRF

IUGG

IUGS

IUSS

IYPE

UN

UNCE-GGIM

UNEP

UNESCO

UNISDR

URSI

WCRP

WDS

WMO

VASAG
International Society for

Photogrammetry and Remote

Sensing

International Social Sciences

Council

International Telecommunication Union

International Terrestrial Reference

Frame

International Union of Geodesy

and Geophysics

International Union of Geological

Sciences

International Union of Soil

Sciences

International Year of Planet Earth

United Nations

UN Committee of Experts on

Global Geospatial Information

Management

UN Environment Programme

United Nations Educational,

Scientific and Cultural

Organization

United Nations Office for Disaster

Risk Reduction

International Union of Radio

Science

World Climate Research

Programme

ICSU World Data System

World Meteorological

Organization

Joint WMO-IUGG Volcanic Ash

Scientific Advisory Group

ICAO International Civil Aviation

Organization

ICSU International Council for Science

ICTP Abdus Salam International Centre for

Theoretical Physics

IGC International Geological Congress

IGCP International Geoscience Programme

IGRF International Geomagnetic Reference

Field

IGU International Geographical Union

IGY International Geophysical Year

IHP International Hydrological Programme of UNESCO

IHY International Heliophysical Year

ILP International Lithosphere Program

INQUA International Union for Quaternary

Research

IOC Intergovernmental Oceanographic

Commission of UNESCO

IPCC Intergovernmental Panel on

Climate Change

IPY International Polar Year

IRC International Research Council

IRDR Integrated Research on Disaster

Risk Programme 
Acknowledgements. I am very thankful to Ester Sztein (Board on International Scientific Organizations of the US National Academy of Sciences), who motivated the author to analyse the role that international scientific unions play in the modern scientific arena. I am very grateful to my colleagues Tom Beer, Claude Boucher, Harsh Gupta, Alexei Gvishiani, Aksel Hansen, Chris Rizos, Uri Shamir, Michael Sideris, and Hans Volkert for fruitful discussions on the topics of international scientific organisations, professional societies of geoscientists, and international cooperation in geosciences. JoAnn Joselyn, Steve Sparks, Kendall Stiles, Ester Sztein, and Kathy Whaler are acknowledged for their thorough review of the initial manuscript and their constructive comments. The author is very grateful to Editor Greg Good and two anonymous reviewers for their in-depth review of the initial manuscript and constructive comments, which improved the paper. Although this research was not supported by any organisations, I would like to acknowledge the International Union of Geodesy and Geophysics (IUGG) and the German Science Foundation (DFG) for providing a travel support allowing me to visit international events around the world and to learn more about international geoscience cooperation.

Edited by: G. A. Good

Reviewed by: H. Volkert and one anonymous referee

\section{References}

Adams, J.: The fourth age of research, Nature, 497, 557-560, 2013. AGU: Annual Report 2012, Washington, D.C.: American Geophysical Union, available at: http://about.agu.org/files/2013/12/ 2012-Annual-Report.pdf (last access: 3 May 2016), 2012.

Angus-Leppan, P. V.: A note on the history of the International Association of Geodesy, J. Geodesy, 58, 224-229, 1984.

Asher, P. and Saltzman, J.: Middle and high school students shine, EOS, 93, p. 96, 2012.

Ashford, O. M.: The launching of the Global Atmospheric Research Programme (GARP), Weather, 37, 265-272, 1982.

Ball, J., Davidson, E., Holloway, T., Holmes, M. A., McKenzie, J. A., Mukasa, S., Paredes, B., Pieters, C., Sivapalan, M., and Vrugt, J.: Improving your success in AGU honors, EOS, 96, doi:10.1029/2015EO026143, 2015.

Bauer, L. A.: Geophysics at the Brussels meetings, Science, 50, 399-403, 1919.

Bernauer, T., Kalbhenn, A., Koubi, V., and Spilker, G.: Is there a "Depth versus Participation" dilemma in international cooperation?, Rev. Int. Org., 8, 477-497, 2014.

Bolin, B.: A History of the Science and Politics of Climate Change: The Role of the Intergovernmental Panel on Climate Change, Cambridge University Press, Cambridge, UK, 277 pp., 2007.

Bormann, P. (Ed.): New Manual of Seismological Observatory Practice (NMSOP-2), IASPEI and GFZ German Research Centre for Geosciences, Potsdam, Germany, doi:10.2312/GFZ.NMSOP2, 2012.

Chapman, S.: Early international co-operation in geonomy, IUGG Newsletters, 10, 271-273, 1955.

Cohen, K. M., Finney, S. C., Gibbard, P. L., and Fan, J.-X.: The ICS International Chronostratigraphic Chart, Episodes, 36, 199-204, 2013.
Collier, P.: Edward Sabine and the "Magnetic Crusade", in: History of Cartography, edited by: Liebenberg, E., Lecture Notes in Geoinformation and Cartography, Springer, Berlin-Heidelberg, 309-323, 2014.

Cutter, S., Ismail-Zadeh, A., Alcántara-Ayala, I., Altan, O., Baker, D. N., Briceño, S., Gupta, H., Holloway, A., Johnston, D., McBean, G. A., Ogawa, Y., Paton, D., Porio, E., Silbereisen, R. K., Takeuchi, K., Valsecchi, G. B., Vogel, C., and Wu, G.: Pool knowledge to stem losses from disasters, Nature, 522, 277-279, 2015.

Derbyshire, E. (Ed.): Tales Set in Stone - 40 Years of the International Geoscience Programme (IGCP), UNESCO, Paris, France, 142 pp., 2012.

Davies, A. (Ed.): Forty years of progress and achievement: A historical review of WMO, WMO publ. No. 721, available at: http://library.wmo.int/pmb_ged/wmo_721_en.pdf (last access: 25 November 2016), 1990,

Doel, R. E. and Needell, A. A.: Science, scientists, and the CIA: balancing international ideals, national needs, and professional opportunities, Intelligence and National Security, 12, 59-81, 1997.

Doel, R. E., Hoffmann, D., and Krementsov, N.: State limits on international science: a comparative study of German science under Hitler, Soviet science under Stalin, and U.S. science in the Early Cold War, Osiris, 20, 49-76, 2005.

Fierz, C., Armstrong, R. L., and Durand, Y.: The International Classification for Seasonal Snow on the Ground, IHP-VII Technical Documents in Hydrology No. 83, IACS Contribution No. 1, UNESCO-IHP, Paris, France, 2009.

Fleming, J. R.: Inventing atmospheric science: Bjerknes, Rossby, Wexler, and the foundations of modern meteorology, The MIT Press, Cambridge, MA, 2016.

Forman, P.: What the past tells us about the future of science, in: La ciencia y la tecnologia ante el tercer milenio, edited by: Sánchez Ron, J. M., Madrid, Sociedad Estatal España Nuevo Milenio, 2737, 2002.

Good, G. A.: The assembly of geophysics: Scientific disciplines as frameworks of consensus, Stud. Hist. Phil. Mod. Phys., 31, 259292, 2000.

Graedel, T. E.: AGU Celebrates 80 Years of Leadership, American Geophysical Union, Washington, D.C., USA, 16 pp., 1999.

Greenaway, F.: Science International: A history of the International Council of Scientific Unions, Cambridge University Press, Cambridge, UK, 280 pp., 1996.

Harrison, J. M.: The roots of IUGS, Episodes, 1, 20-23, 1978.

Hildebrandsson, H. H. and Hellmann, G.: Codex of resolutions adopted at International Meteorological Meetings, 1872-1907, Nature, 81, p. 5, 1907.

IAPSO: The history of IAPSO dates from the early years of the 20th century: Potsdam, International Union of Geodesy and Geophysics, available at: http://iapso.iugg.org/home-iapso8/ general-information 16.html? showall=\&start=1 (last access: 3 May 2016), 2015.

IAVCEI Subcommittee for Crisis Protocols: Professional conduct of scientists during volcanic crises, Bull. Volcan., 60, 323-334, 1999.

ICSU: Decisions of the 31st General Assembly of ICSU, Auckland, New Zealand, 31 August-3 September 2014, available at: http://www.icsu.org/publications/general-assembly/ 31st-general-assembly-auckland-new-zealand-2014/ 
decisions-31st-general-assembly-english (last access: 25 November 2016), 2014.

IOC-SCOR-IAPSO: The International Thermodynamic Equation of Seawater - 2010: Calculation and Use of Thermodynamic Properties, Intergovernmental Oceanographic Commission, Manuals and Guides No. 56, UNESCO-IOC, Paris, France, 2010.

IRC: The Brussels meeting of the International Research Council, Science, 50, p. 226, 1919.

Ismail-Zadeh, A. and Beer, T.: International cooperation in geophysics to benefit society, EOS, 90, 501-502, 2009.

Ismail-Zadeh, A. and Cutter, S. (Eds.): Disaster Risks Research and Assessment to Promote Risk Reduction and Management, International Council for Science and the International Social Sciences Council, Paris, France, available at: http://www.icsu.org/science-for-policy/disaster-risk/documents/ DRRsynthesisPaper_2015.pdf (last access: 29 February 2016), 2015.

ITRF: The International Terrestrial Reference Frame, 2014 release, available at: http://itrf.ensg.ign.fr/ITRF_solutions/2014 (last access: 3 May 2016), 2014.

IUGG: Addresses at the opening assembly of the International Union of Geodesy and Geophysics on 6 Sep. 1939, Science, 90, 339-345, 1939.

IUGG: Report of the Union for the War Years 1939-1945, edited by: Stagg, J. M., Cambridge, UK, 158 pp., 1946.

IUGG: On the IUGG Statement on Volcanic Ash Cloud, IUGG EJournal, 10, p. 2, available at: http://www.iugg.org/resolutions/ VAC_IUGG_Statement_20April.pdf (last access: 3 May 2016), 2010a.

IUGG: The IUGG Statement "Volcanological and Meteorological Support for Volcanic Ash Monitoring”, IUGG E-Journal, 10, 1-2, available at: http://www.iugg.org/resolutions/IUGG_ Statement_VMSVolcAshMonit.pdf (last access: 29 February 2016), 2010b.

IUGG: The IUGG Statement on Freedom to Conduct Science and Responsibilities of Scientists, IUGG E-Journal, 10, 1-2, available at: http://www.iugg.org/resolutions/IUGG_for_freedom_ to_conduct_science.pdf (last access: 29 February 2016), 2010c.

IUGG: Annual Report, International Union of Geodesy and Geophysics, edited by: Ismail-Zadeh, A., Potsdam, Germany, available at: http://www.iugg.org/publications/reports/report2012.pdf (last access: 3 May 2016), 2012.

IUGG: The Statutes and By-Laws of the International Union of Geodesy and Geophysics, available at: http://www.iugg.org/ statutes (last access: 3 May 2016), 2015.

Jacobs, F. and Börngen, M.: Zu den Wurzel von IASPEI - Die Permanente Kommission für internationale Erdbebenforschung 1899-1903, DGG Mitteilungen, No. 2/2012, 30-38, available at: https://dgg-online.de/WordPress_01/wp-content/ uploads/2016/04/DGG-Mitt_2-2012.pdf (last access: 25 November 2016), 2012.

Launius, R. D., Fleming, J. R., and DeVorkin, D. H. (Eds.): Globalizing polar science: reconsidering the International Polar and Geophysical Years, Plagrave Macmillan, New York, 386 pp., 2010.
Linthe, H.-J.: Observatories in Germany, in: Encyclopedia of Geomagnetism and Paleomagnetism, edited by: Gubbins, D. and Herrero-Bervera, E., Springer, Dordrecht, the Netherlands, 729731, 2007.

Lyons, H. G.: The Brussels meeting of the International Research Council, Nature, 103, 464-466, 1919.

Lyons, H. G.: The International Union of Geodesy and Geophysics, Nature, 109, 758-759, 1922.

Olson, M.: The Logic of Collective Action: Public Goods and the Theory of Groups, Harvard University Press, Cambridge, MA, USA, 186 pp., 1965.

Plag, H.-P. and Pearlman, M. (Eds.): Global Geodetic Observing System: Meeting the Requirements of a Global Society on a Changing Planet in 2020, Springer, Berlin-Heidelberg, 332 pp., 2009.

Rackham, H.: Translation of the Aristotle's work Nicomachean Ethics ( 340 BC). Aristotle in 23 Volumes, Vol. XIX, Harvard University Press, Cambridge, MA, USA, 688 pp., 1926.

Rohde, H.: Bert Bolin (1925-2007) - a world leading climate scientist and science organiser, Tellus B 65, 1-6, 2013.

Schweitzer, J.: The early German contribution to modern seismology, in: International Handbook of Earthquake and Engineering Seismology, edited by: Lee, W., Kanamori, H., Jennings, P., and Kisslinger, C., Elsevier, Berlin, 1347-1350, 2003.

Scientific Events: International science and the war, Science, 50, 453-454, 1919.

Showstack, R.: Geoscientists: focus more on societal concerns, EOS, 96, 4-5, 2015.

Sztein, A. E: Science diplomacy in the geosciences, in: Communicating Climate-Change and Natural Hazard Risk and Cultivating Resilience, edited by: Drake, J. L., Kontar, Y. Y., Eichelberger, J. C., Rupp, T. S., and Taylor, K. M., Springer, Cham, Switzerland, 279-294, 2016.

Thébault, E., Finlay, C. C., Beggan, C. D. et al.: International Geomagnetic Reference Field: the 12th generation, Earth Planet. Space, 67, 1-19, doi:10.1186/s40623-015-0228-9, 2015.

Van Baren, H., Hartemink, A. E., and Tinker, P. B.: 75 years of the International Society of Soil Science, Geoderma, 96, 1-18, 2000.

Weart, S. R.: The evolution of international cooperation in climate science, J. Int. Organ. St., 3, 41-59, 2012.

WMO: Working Arrangements with the International Union of Geodesy and Geophysics, in: The World Meteorological Organization Basic Documents No. 3. Agreements and Working Arrangements with other international organizations. 2002 edition, WMO-No. 60, 129-130, Geneva, WMO, available at: http: //library.wmo.int/pmb_ged/wmo_60_en-2002.pdf, 2002.

Wood, H. O.: Organization of the American Section of the International Geophysical Union, Science, 50, 233-238, 1919a.

Wood, H. O.: Organization of the American Section of the International Geophysical Union, Science, 50, 255-258, 1919 b.

Wulf, A.: The Invention of Nature: Alexander von Humboldt's New World, Alfred A. Knopf Publishing Group, New York, 496 pp., 2015 . 